\title{
DIRGLIŲ GERKLŲ SINDROMAS: ŠIUOLAIKINE DIAGNOSTIKA IR GYDYMAS
}

\author{
Nora Šiupšinskienè $\dot{1}^{1,2}$, Asta Aukštakalniené $\dot{e}^{3}$, Sigutė Norkiené $\dot{e}^{1,4}$ \\ ${ }^{1}$ Klaipedos universitetas, ${ }^{2}$ Lietuvos sveikatos mokslu universiteto ligoninès Kauno klinikos, Ausu, \\ nosies, gerklès ligu klinika, ${ }^{3}$ Lietuvos sveikatos mokslu universiteto ligoninès Kauno klinikos, \\ Šeimos medicinos klinika, ${ }^{4}$ Klaipédos jürininku ligoninè
}

Raktažodžiai: dirglių gerklų sindromas, paradoksiniai balso klosčiu judesiai, sensorinè neuropatija, priežastys, diagnostika, gydymas, hidracija.

\begin{abstract}
Santrauka
Straipsnyje detaliai nagrinejjama suaugusių asmenų dirglių gerklų sindromo terminai, patogenezè ir priežastys, aprašoma dirglių gerklų sindromo diagnostika atsižvelgiant ị anamnezę, simptomus ir laringoskopijos požymius. Straipsniu supažindinama su šiuolaikiškais dirglių gerklų sindromo gydymo principais, paremtais ligos pripažinimu, balso terapija, psichoterapija ir elgesio terapija bei gydymu neuromoduliatoriais. Aprašoma balso higienos ir hidracijos nauda.
\end{abstract}

\section{Ivadas}

Gerklos tampa dirglios dèl per didelès dozès egzogeninių ir endogeninių dirgiklių, kurie sukelia ilgai trunkančius neuroplastinius pokyčius smegenyse ir sąlygoja gerklų raumenų netinkamą naudojimą [1]. Pacientai, kuriems pasireiškia dirglių gerklų sindromas (DGS), skundžiasi pasikartojančiais gerklų spazmo epizodais, jų metu dažniausiai pasunkèja ikvėpimas [1,2]. Pasireiškus DGS, pacientai skundžiasi dusuliu, stridoru, disfonija, lètiniu atkakliu kosuliu, „kąsnio“ pojūčiu ryklèje ir/ar krenkštimu. Kadangi gerklų hiperfunkcija sukelia epizodinę ūmią kvèpavimo takų obstrukciją, tokiems pacientams dažnai neteisingai diagnozuojama astma, kvėpavimo takų svetimkūniai, organinès gerklų ligos, gerklų paralyžius, todèl be reikalo atliekama daug tyrimų, tokie pacientai patiria nereikalingų chirurginių intervencijų, pavyzdžiui - intubaciją ar tracheostomiją, taip pat šiems pacientams skiriama daug skirtingų vaistų, kurie dažnai būna neveiksmingi [3-5]. Tyrimais nustatyta, kad sunkiai gydymui pasiduodanti astma nustatoma pirmiausia daugiau nei dviem trečdaliams tokių pacientų [3]. Sergantiems DGS apžiūros metu stebimi gerklų raumenų hipertonuso požymiai
- balso klosčių suspaudimas priekine-užpakaline kryptimi, paradoksiniai balso klosčių (BK) judesiai, įsitempę kaklo ir pečių juostos raumenys. Tokiems pacientams kartu dažnai nustatoma gastroezofaginio refliukso ligos laringofaringinė forma (GERL LF), galimas psichoemocinis disbalansas [2,6].

Šio darbo tikslas buvo atlikti šiuolaikinès literatūros analizę ir įvertinti DGS sindromo priežastis, diagnostiką ir šiuolaikinio gydymo principus.

\section{Darbo metodika}

Atlikta duomenų paieška elektroninėse duomenų bazèse PubMed, MEDLINE ir EMBASE 1999-2016 metu laikotarpiu. Paieškos žodžiai: paradoksiniai balso klosčių judesiai, funkcinė kvėpavimo takų obstrukcija, netikra astma, paradoksinè balso klosčių disfunkcija, epizodinè gerklu diskinezija, psichogeninis stridoras, gerklų hiperjautrumas, gerklų hiperjautrumo sindromas, epizodinis paroksizminis gerklų spazmas, laringofaringinè neuropatija, povirusinè klajoklio nervo neuropatija, idiopatinè gerklų sensorinė neuropatija, neurogeninis kosulys; dirglių gerklų diagnostikos ir gydymo metaanalizès ir apžvalgos. Atlikta 29 tyrimų ir apžvalgų analizė.

\section{Rezultatai ir jų aptarimas}

Terminai. Istoriškai šiai patologijai apibūdinti naudojama daug skirtingų terminų - tai paradoksiniai balso klosčių judesiai, funkcinè kvépavimo takų obstrukcija, netikra astma, paradoksinẻ balso klosčių disfunkcija, epizodinė gerklu diskinezija, psichogeninis stridoras, gerklų hiperjautrumas, gerklų hiperjautrumo sindromas, epizodinis paroksizminis gerklų spazmas ir nuo $1999 \mathrm{~m}$. Morrison su kolegomis įvestas ir plačiausiai paplitęs terminas - dirgliu gerklų sindromas [1-6]. Taip pat šis sindromas susijęs su tokiais terminais kaip laringofaringine neuropatija, povirusine klajoklio nervo neuropatija, idiopatine gerklų sensorine neuropatija ar neurogeniniu kosuliu [7-13]. 
Atsižvelgiant ị šiuolaikinius apibendrintus mokslinès literatūros duomenis, DGS priskiriamas epizodinėms gerklų kvèpavimo ligoms (angl. Episodic laryngeal breathing disorders) [5]. Pacientams, segantiems šiuo sindromu, dažnai kliniškai kartu pasireiškia paradoksiniai balso klosčiu judesiai, kurie šiuo atveju yra sudètinè dirglių gerklų sindromo dalis. DGS taip pat gali persidengti su kitais sindromais jeigu kliniškai kartu pasireiškia atkaklus lètinis kosulys, gali būti diagnozuojamas kosulio hiperjautrumo sindromas. Šis sindromas apima ne tik viršutinius kvèpavimo takus, pirmiausia gerklas, nes jose yra didžiausia kosulio receptorių koncentracija, bet ir apatinius kvèpavimo takus ir turi panašią į DGS patogenezę [14-16].

Dirglių gerklų sindromas - tai epizodiškai pasikartojantys gerklų spazmai, lydimi disfonijos ir kosulio bei gerklų parestezijos, susiję su padidẻjusiu gerklų jautrumu skirtingiems dirgikliams $[1,2,5,6]$.

Gerklų spazmas - tai gerklų plyšio spazminis užsidarymas ar staigus, su jëga ir nenormalus balso klosčių užsivèrimas $[1,2,5,6]$.

Paradoksiniai balso klosčių judesiai - neteisingi adukciniai (suartejjimo) gerklų - t.y. balso klosčių ir/ar gerklų prieangio struktūrų judesiai ịkvejpimo ir/ar iškvejpimo metu, kurie gali būti pirminiai bei antriniai [3].

Kosulio hiperjautrumo sindromas - tai viršutinių ir apatinių kvépavimo takų juntamujų nervų patologija, pasireiškianti lètiniu atkakliu kosuliu, kaip atsaku ị netoksiškus ir toksiškus dirgiklius dèl padidejjusios kosulio receptorių - tranzitorinio potencialo vaniloidinių 1-ojo tipo ir A1 receptorių raiškos $[14,15,17]$.

Dirglių gerklų sindromo patogenezė. Moksliniai tyrimai parodè, kad dirglios gerklos išsivysto dèl igyto smegenų, ypač prie vandentiekio esančios pilkosios medžiagos, neuroplastiškumo [1,2]. Dèl kartotinio kvėpavimo takus veikiančių dirgiklių poveikio, hiperaktyvuojami aferentiniai neuronai (pasiruošę sukelti laringospazmą, atkaklų kosulį) ir pasikeičia centrinè gerklų ir aplinkinių audinių neurogeninè kontrolè, ịvardijant šį procesą kaip „,neuroplastiškumą“ $[2,14]$. Taigi, šio proceso metu yra pažeidžiamas atsakas i adekvatu jutimini stimulą. Skirtingos kilmès nespecifiniai uždegiminiai mediatoriai ijautrina klajoklio nervo inervuojamų organų gleivinių aferentinius nervus per jų galūnėlių greito impulso plitimo skaidulas (vadinamąsias $\mathrm{C}$ tipo, neturinčių mielino skaidulas), tokiu būdu sumažindami jutiminių receptorių slenksčius [2,9]. Atkaklaus lètinio kosulio atveju, šis procesas yra susijęs su padidejusia tranzitorinio potencialo vaniloidinių 1-ojo tipo receptorių raiška ne adrenerginèse ir ne cholinerginèse nervų galūnėlèse [9]. CNS ịjautrinimas charakterizuojamas padidejjusiu sužadinimu centriniuose jutiminiuose laiduose. Centrinị ijautrinimą rodo gerklų jau- trumo pokyčiai atliekant objektyvius gerklų jautrumo mėginius, gerklų hiperjautrumas ar parestezijos, pasireiškiančios pakitusiais pojūčiais ryklëje (kutenimas, niežulys, „kąsnis“); sustiprèjęs gerklų atsakas (spazminis kosulys) į adekvačius stimulus, pavyzdžiui, dūmus, rūkymą, aspiratą bei sustiprèjęs gerklų atsakas į neadekvačius stimulus, pavyzdžiui, temperatūros svyravimus, balso vartojimą, fizinius pratimus $[9,18]$. Be to, naujausi tyrimai atskleide, kad šiems pacientams padideja smegenų žievès aktyvumas, fiksuojamas funkcinio magnetinio rezonanso metu [9]. Taip pat šiems pacientams nustatomi pasikeitę skausmo slenksčiai [9].

Dirglių gerklų sindromo priežastys. Vieni dažniausių dirgiklių, veikiančių gerklas ir siejamų su DGS, aprašytų Morrison ir kolegu, yra pasikartojantis refliuksato poveikis gerklu gleivinei bei beveik pusei pacientų nustatyta persirgta virusinè infekcija [1,2]. Šiuos dirgiklius patvirtino ir vèlesni kitų autorių tyrimai $[4,8,9,12]$. Kiti mokslinėje literatūroje nurodomi išoriniai provokuojantieji dirgikliai - tai skirtingi kvapai, dūmai, temperatūrų pokytis, su tam tikrų darbų specifika susiję dirgikliai, be to, epizodini laringospazmą gali išprovokuoti kalbejjimas, dainavimas ir kosulys [1-7, 11,12]. Andrianopoulos su kolegomis, ištyrę 27 pacientus su DGS, nustatè, kad daugiau nei trečdalis pacientų DGS būdingus simptomus siejo su emociniais faktoriais - stresu ir nerimu, 22 proc. pacientų simptomų pradžia sutapo su tam tikrų maisto produktų - riešutų svieto, salotų padažų, greifrutų, riešutų ir kt. vartojimu [4].

Daugumos autorių nuomone, DGS reišmingai dažniau pasireiškia vidutinio amžiaus moterims nei vyrams $[1,2,4,12,19]$. Tai gali lemti didesnis moterims nei vyrams nustatomas tranzitorinio potencialo kosulio receptorių jautrumas ar sumažejęs moterims estrogeno kiekis klimakso metu, kas skatina kosulio reflekso suaktyvejjimą [9].

Dirglių gerklų sindromo diagnostika. Pagrindiniai diagnostiniai DGS kriterijai, yra šie $[1,2,12]$ :

1. Simptomai, susiję su gerklų įsitempimu:

- Disfonija ir/ar gerklų spazmas (stridoras/dusulys);

- „Kąsnio“ pojūtis ir /ar lètinis kosulys.

2. Apžiūros metu nustatomi galvos-kaklo raumenų ịsitempimo požymiai:

- Laringoskopijos metu nustatomas gerklų raumenų įsitempimas fonuojant - stebima balso klosčių, vestibulinių klosčių hiperadukcija (ventrikulinè fonacija, kai gerklos suartejja medialine-lateraline kryptimi) ir/ar ịvairaus laipsnio priekinis - užpakalinis gerklų susitraukimas, kai gerklos suarteja priekinè-užpakaline kryptimi; taip pat galima stebėti susiformuojantį “užpakalinį" balso plyšio trikampi ar rombą dèl fonacijos metu išlikusio užpakalinio skydinio vedegos raumens ( $m$. thyroarythenoideus posterior), kuris yra atsakingas už balso klosčių abdukciją (t.y. nutolimą), îsitempimo 
(1 pav); gali būti ryškus ryklès refleksas.

- Čiuopiami skausmingi, ịsitempę virš poliežuvinès ir po poliežuvinès sričių raumenys. Taip pat čiuopiant gali būti nustatoma aukšta gerklu padètis, skausmingi gerklų srities taš-

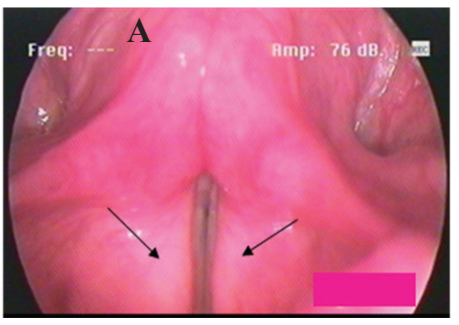
dialinè-lateralinè hiperkinezè) kai.

3. Nustatomas simptomų ryšys su tam tikrais dirgikliais (inhaliacinès medžiagos, stemplès dirgikliai, kvapai).

Simptomai. DGS būdingas staigus ryklès kutenimo, peršejimo priepuolis, lydimas dusulio su stridoru, atkaklaus kosulio su ašarojimu, rinoreja ir išraudimu [12]. Reikia pažymèti, kad stridoras, dusulio priepuoliai ir atkaklus kosulys yra dažniausiai pasireiškiantys simptomai, kurie pirmiausia

1 lentelè. Paradoksinių balso klosčių judesių priežastys [3] OMA - obstrukciné miego apnéja.

\begin{tabular}{|l|}
\hline Pirminiai paradoksiniai balso klosčiu judesiai \\
\hline $\begin{array}{l}\text { Psichologiniai disociaciniai (konversiniai sutrikimai) } \\
\text { (70 proc. atvejų) }\end{array}$ \\
\hline Simuliacija (5 proc.) \\
\hline $\begin{array}{l}\text { Antriniai paradoksiniai balso klosčių judesiai } \\
\text { (25 proc. atvejų) }\end{array}$ \\
\hline Dirglios gerklos \\
\hline Astma \\
\hline Refliuksas \\
\hline Alerginis laringitas \\
\hline Sausasis laringitas \\
\hline Gerklu kandidozė \\
\hline Nosies-prienosinių ančių ligos \\
\hline Negydoma OMA \\
\hline Gerklų sensorinė neuropatija \\
\hline Neurologinės ligos \\
\hline $\begin{array}{l}\text { Židininė kvėpavimo distonija su ar be spazminės disfonijos; iš- } \\
\text { sėtinė sklerozė; autonominè disfunkcija }\end{array}$ \\
\hline Diferencinė diagnostika \\
\hline Balso klosčiu paralyžius: abipusis/vienpusis \\
\hline Gerklų stenozė \\
\hline Laringomaliacija/ tracheomaliacija \\
\hline Fizinių pratimų sukelta hipoksija \\
\hline Tonziliu (gomurio, liežuvio) hipertrofija \\
\hline Gerybiniai /piktybiniai kvėpavimo takų navikai \\
\hline Atspari gydymui astma \\
\hline
\end{tabular}

Gerklų raumenų įsitempimas (me-

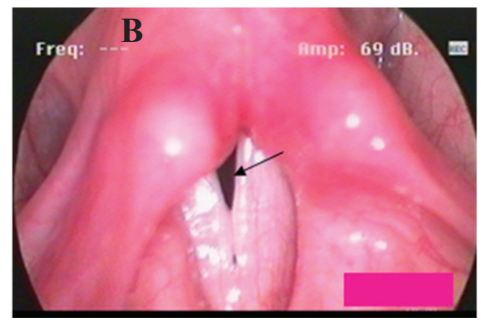

„Užpakalinis“ balso plyšio trikampis dèl $\mathrm{m}$. thyroarythenoideus posterior isitempimo fonacijos metu

1 pav. Pacientų su dirglių gerklų sindromu vaizdolaringoskopijos duomenys. Asmeninis archyvas (A, B). Patologija pažymėta rodyklèmis

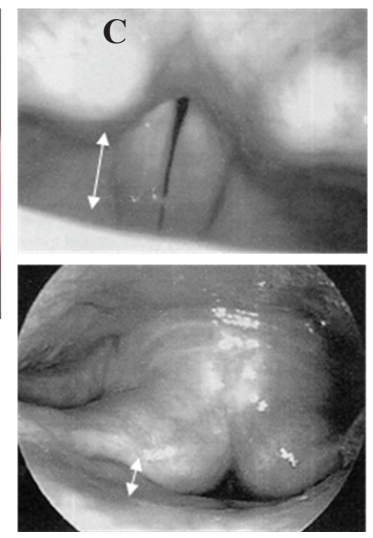

Skirtingo laipsnio priekinis - užpakalinis gerklų susitraukimas

vargina apie du trečdalius DGS pacientų [1-4]. Tačiau arti pusès DGS pacientų taip pat gali išsivystyti ūmi ar pasikartojanti afonija (bebalsystė) [4]. DGS pacientams, skirtingai nuo sergančių GERL LF, būdingesnis dieninis, sausas kosulys, kuris dažnai yra lojančio pobūdžio ir susijęs su kalbèjimu [3]. Dažnai šiems, DGS sergantiems pacientams, kosulys pasireiškia apžiūros metu fonuojant.

(Vaizdo) laringoskopija. Vienas iš galimų DGS laringologinių požymių - laringoskopijos metu nustatomi paradoksiniai balso klosčių judesiai. Pasireikšdami neteisinga BK adukcija (suartejjimu) pacientui kvejpuojant, jie sukelia kvėpavimo sutrikimus, kurie neretai priskiriami gyvybei pavojingoms būklèms [2,3]. Todèl, kaip jau minèta anksčiau, tokiems pacientams dažnai be reikalo atliekama daug tyrimų, skiriama daug skirtingų vaistų, jie patiria nereikalingų chirurginių intervencijų. Reikia atminti, kad paradoksinių BK judesių priežastys yra dauginès ir šis požymis gali pasireikšti ne tik pacientams su DGS. Antrinius paradoksinius BK judesius, kai yra gerklų hiperjautrumas, išprovokuoja gerklų gleivinès dirginimas ịvairiais dirgikliais ar gerklų jautrumo pasikeitimai [3]. 1 lentelèje parodytos pagrindinès šiuo metu žinomos paradoksinių BK judesių priežastys, kurios svarbios atliekant DGS diferencinę diagnostiką [3].

Taip pat daliai pacientų vaizdo laringoskopijos metu gali būti nustatomi subtilūs ar matomi neurologiniai radiniai (parezè), taip pat refliuksato sukelti požymiai $[8,12]$. Be to, sergančiujų DGS galima matyti sausas ryklès ir gerklų gleivines, dažniausiai dèl šalutinio vartojamų vaistų poveikio arba dèl šiems pacientams būdingos dehidratacijos [9].

Diagnozuojant paradoksinius balso klosčiu judesius ir atliekant diferencinę diagnostiką lemiamą reikšmę turi gerklų tyrimas lanksčiu fibroendoskopu. Nuo 2004 m. JAV DGS diagnostikai pradètas naudoti provokacinis kvepalu 
mėginys [20]. Atliekant ši mègini, gerklos fibroendoskopinio tyrimo metu stebimos kvèpuojant ir fonuojant prieš provokacinį stimulą ir ịkvepus jo. Jeigu mèginys teigiamas, fiksuojami paradoksiniai BK judesiai (BK adukcija įkvepiant ir abdukcija fonuojant, sukelianti kosuli, inspiracini dusuli). Tyrimais nustatyta, kad patikimiausias stimulas ikvepiant ir per nosic, ir per burną yra kvepalai [20].

Atsižvelgiant ị simptomus ir požymius, kanadiečių mokslininkai Hoy su kolegomis $2010 \mathrm{~m}$. pasiūlè modifikuotą DGS skriningo diagnostiką: DGS įtariamas, jeigu yra nors vienas iš didžiujų DGS simptomų (didieji simptomai - tai disfonija, susijusi su gerklų raumenų ịsitempimu, ir dusulys; mažieji - „kąsnio“ pojūtis ryklèje ir lètinis kosulys). Neabejotinas DGS nustatomas, jeigu yra nors vienas didysis DGS simptomas, atliekant laringoskopiją patvirtinami gerklų ịsitempimo požymiai ir atmetama akivaizdi organinė gerklų patologija [6]. Kartu nustačius akivaizdžius oro dirgiklius ir kvapus, susijusius su darbu, diagnozuojamas profesinis DGS. DGS diagnostikai palengvinti $2014 \mathrm{~m}$. sukurtas ir validizuotas Niukastlio gerklų hiperjautrumo klausimynas, susidedantis iš 14 specifinių klausimų, apimančių tris sritis - obstrukciją, skausmą/temperatūros pojūčius ir sudirginimą [21]. Klausimynas padeda diagnozuoti DGS bei patikimai sekti šios ligos gydymo veiksmingumą.

Kiti tyrimai. Gerklų jautrumą, kurio pasikeitimai būdingi sergantiems DGS, galima ịvertinti objektyviais metodais: naudojant hipertoninį druskos tirpalą ar fibroendoskopijos metu vedeginius gumburus mechaniškai stimuliuojant oro pliūpsniu ar liečiant fibroskopo galiuku ir sukeliant balso klosčių adukcinį refleksą $[4,8,9,18]$. DGS būdinga padidejjęs gerklų gleivinės chemoreceptorių jautrumas ir sumažèjęs mechanoreceptorių [17].

Nors pagal klasikinius Morrison suformuotus kriterijus DGS nustatomas kai nèra akivaizdžios organinès gerklų patologijos, aiškios neurologinès ar psichiatrinès ligos, šiuolaikiniai tyrimai atskleidžia, kad DGS gali pasireikšti kartu su neurologinėmis gerklų ligomis, gerklų edema, kitomis gerklų obstrukciją galinčiomis sukelti ligomis, astma ir įvairiomis psichiatrinemis ligomis [1-4]. Visgi siekiant skirti teisingą gydymą, pasireiškus šalutinèms ligoms, pirmiausia svarbu

\section{Dirgliụ gerklụ sindromas (DGS)}

\begin{tabular}{|c|c|c|}
\hline \multicolumn{2}{|c|}{ Simptomai } & \multirow{2}{*}{$\begin{array}{c}\text { Laringoskopiniai } \\
\text { duomenys }\end{array}$} \\
\hline & & \\
\hline $\begin{array}{l}\text {-Epizodinis } \\
\text { gerklų spaz mas } \\
\text { (dusulys): } \\
\text { inspiracinis, }\end{array}$ & $\begin{array}{l}\text { •Gerklų } \\
\text { obstrukcija: } \\
\text { balso plyšio, } \\
\text { gerklų prieangi }\end{array}$ & $\begin{array}{l}\text { •Gerklų ju } \\
\text { ikvepiant, } \\
\text { iškvepiant } \\
\text { (paradoksin }\end{array}$ \\
\hline
\end{tabular}

-Gerklų raumenų isitempimo tipas: priekinis-užpakalinis, lateralinis-medialinis
-Krenkštimas

-Kaklo raumenų

isitempimas/ lokalus

skausmas
-Disfonija

-Kosulys

•"Kąsnio" pojūtis

2 pav. Shematinis dirglių gerklų sindromo modelis (modifikuota pagal Shembel, 2016 [5]);

atskirti ir diagnozuoti DGS. Traister su kolegomis nesenai pasiūlè Pitsburgo balso klosčių disfunkcijos indeksą, kuriuo siekiama DGS diferencijuoti nuo astmos ir tokiu būdu laiku skirti teisingą gydymą [19]. Pagal autorius, jeigu yra disfonija, pacientas jaučia „kąsnį“ ar įtampą ryklejje, nëra švokštimo ir nustatomas jautrumas kvapams - t.y. visi keturi Pitsburgo balso klosčių disfunkcijos indekso kintamieji yra teigiami - absoliučiai daugumai tirtų pacientų $(77,8$ proc. tikimybe) nustatomas DGS.

Šiuolaikinè mokslinès literatūros analize, apimanti 19832015 m. laikotarpi, atlikta amerikiečių mokslininkų, igalino

2 lentelè. Apibendrinti neuromoduliatorių, skirtų gydyti atkaklų, lètinį kosuli, sisteminès analizès duomenys [13]

Šiais vaistais pradedama gydyti nuo mažu doziu ir didinama iki optimalių; vaistai nutraukiami mažinant dozę;

* - labai mažas tirtu pacientu skaičius.

\begin{tabular}{|l|c|c|c|}
\hline $\begin{array}{l}\text { Vaistas (publika- } \\
\text { cijų skaičius) }\end{array}$ & Dozė & $\begin{array}{c}\text { Gydymo } \\
\text { trukmé }\end{array}$ & $\begin{array}{c}\text { Pagerè- } \\
\text { jimas (paci- } \\
\text { entų proc.) }\end{array}$ \\
\hline Amitriptilinas (3/8) & $10-100 \mathrm{mg} / \mathrm{d}$. & $10-21 \mathrm{~d}$. & $75-86$ \\
\hline Gabapentinas (3/8) & $\begin{array}{c}100-1800 \mathrm{mg} / \mathrm{d} . \\
\text { per 2-3 kartus }\end{array}$ & $4-12 \mathrm{sav}$. & $69-83$ \\
\hline Pregabalinas (1/8) & $\begin{array}{c}150-300 \mathrm{mg} / \mathrm{d} . \\
\text { per 2 kartus }\end{array}$ & 4 sav. & 60 \\
\hline Baklofenas* (1/8) & $\begin{array}{c}30 \mathrm{mg} / \mathrm{d} \text {. per 3 } \\
\text { kartus }\end{array}$ & 4 sav. & 90 \\
\hline $\begin{array}{l}\text { Karbamazepinas* } \\
(1 / 8)\end{array}$ & $\begin{array}{c}200 \mathrm{mg} / \mathrm{d} \text {. per 2 } \\
\text { kartus }\end{array}$ & $\begin{array}{c}\text { 4 sav.; ne- } \\
\text { toleruojant } \\
\text { gabapen- } \\
\text { tino }\end{array}$ & \\
\hline
\end{tabular}


pasiūlyti dirglių gerklų sindromo teorinị diagnostikos modelị [5]. Tai konceptualus modelis, kuris apima DGS sukeliančius veiksnius bei būdingus DGS simptomus ir gerklų požymius (2 pav.).

Dirglių gerklų sindromo gydymo principai. Pagrindiniai DGS veiksmingo gydymo principai apima šiuos aspektus:

- Sąmoningą ligos pripažinimą ir balso higieną (paciento mokymas - priežasčių žinojimas ir šalinimas; adekvataus balso režimo laikymasis, dirgikliu vengimas, sisteminio ir vietinio poveikio hidracija, sveika mityba).

- Balso terapiją: taisyklingo kvèpavimo ir kalbėsenos elgesio pakeitimo pagrindų ịgijimą ir ịtvirtinimą (biologinio - atgalinio ryšio, naudojant vaizdo laringoskopiją, metodika bei kitos metodikos).

- Gydymą neuromoduliatoriais.

- Psichoterapiją, elgesio terapiją.

- Šalutinių ligų gydymą (GERL LF ir kitų).

- Kitas priemones - lokalu gerklų jautrumo gydymą.

XXI a. pradžioje Masačiutseso universiteto Kalbos, balso ir klausos centre sergantiems DGS pasiūlyta veiksminga edukacinè neurolingvistinio programavimo sistema [4]. Programavimas susideda iš trijų stadijų: 1) sąmoningo problemos pripažinimo, kurios metu pacientas apmokomas suprasti problemos priežastis, esmę ir gydymo tikslus; 2) asociacinès stadijos, kurios metu pacientas mokomas automatinès kvėpavimo ir gerklų disfunkcijos kontrolès, pasitelkiant garsinius, vaizdinius, instrumentinius ir proprioreceptoriu poveikio biologinius-atgalinius ryšius (užsienyje populiarūs vaizdo laringoskopijos seansai skirti pakeisti elgesị ị stimulą biologinio atgalinio ryšio pagalba; skiriami 2-5 seansai) ir 3) autonominès stadijos, kurios metu igyti kontrolès ịgūdžiai yra ịtvirtinami - automatizuojami.

Apmokant pacientus taip pat svarbu ịdiegti ilgalaikius balso higienos pagrindus, kurie apima fonaciniu ir nefonacinių veiksmų sistemą, padedančią apsauganti balsą nuo pažeidimo - tai balso ramybè, hidracija, gerklų dirgiklių rūkymo, pramonès ir kitų vengimas, taisyklinga kalbėsena, balso stiprinimo ir lavinimo pagrindai $[8,9]$.

Hidracija yra viena pagrindinių balso saugos priemonių. Rekomenduojama drèkinti patalpas, pakankamai gerti skysčių, vengti dehidrantų - kavos, juodosios arbatos, alkoholio, dehidruojančių vaistų (antihistamininiai, anticholinerginiai, diuretikai), praktikuoti nosies higieną ir vartoti vietinio poveikio hidrantus.

Sistemine ir vietinio poveikio hidracija turi svarbią reikšmę gydant pacientus, sergančius DGS $[4,6,8,9,18]$. Kadangi DGS pacientams būdingas kosulys ir krenkštimas, rekomenduojama gurkštelti vandens ar sąmoningai ryti seiles, kai tik norisi kosèti ir/ar krenkšti (kosulị slopinančio rijimo metodas; angl. cough suppression swallow). Taip pat dèl gerklų hiperjautrumo rekomenduotini gleivinių jaudrumą mažinantys vietinio poveikio vaistai, pavyzdžiui - sukralfato eliksyras bei vietinio poveikio hidrantai su hialurono rūgštimi [3].

Vietinio poveikio hidrantai. Moksliniais tyrimais nustatyta, kad produktai, turintys gleivinę drèkinančių savybių, yra svarbūs kompleksiškai gydant gerklų patologiją. Sukurti vietinio poveikio hidrantai, ị kurių sudètį įeina hialurono rūgštis, parode, kad vietiškai vartojama hialurono rūgštis išsaugo skysčius burnaryklès ir gerklaryklès gleivinèje, padengia šių sričių ir gerklų įeigos gleivinę apsauginiu sluoksniu, turi higroskopinių, gleivinių regeneraciją ir žaizdų gijimą skatinančių savybių, todèl tinka "sausų" ir dirglių gleivinių, ūmaus, lètinio ir opinio uždegimo gydymui $[22,23]$.

Naujausiais, Vokietijoje atliktais tyrimais nustatyta, kad sukurtas kompleksinis hialurono rūgšties ir mineralų (natris, kalis, cinkas, silicis), skatinančių seilių išsiskyrimą, vietinio poveikio preparatas čiulpiamų pastilių forma (GeloRevoice ${ }^{\mathrm{O}}$ ), suformuoja hidrogelio kompleksą, padengdamas burnaryklès, gerklaryklès, antgerklio ir užpakalinès gerklų dalies (gerklų įeigos) gleivinių paviršių hialurono rūgšties prisotintu apsauginiu sluoksniu ir reikšmingai, per tris paras, sumažindamas ryklès ir gerklų sudirginimo simptomus: ryklès peršejimą, kutenimą, kosulį, krenkštimą, „kąsnio“ ir sausumo pojūtį ryklèje, sunkumą ryjant ir užkimimą $[23,24]$. Todèl šis preparatas yra tinkamas kompleksiškai gydant dirglių gerklų sindromą. İvertinus 965 pacientų, kurie buvo tirti 326 medicinos centruose duomenis, nustatyta, kad daugumai (60 proc.) pacientų hidrogelio kompleksas ant gleivinių išlieka $>1$ valandą [24].

Balso terapija. Taisyklingos kalbėsenos formavimas pirmiausia apima diafragminio kvépavimo įsisavinimą [25]. Taikomos dūsavimo, uodimo, pūtimo ir kitos kvẻpavimo technikos [4]. Kartu, pasitelkiant specialius fizinius ir ortofoninius pratimus, mažinamas galvos-kaklo raumenu i̊sitempimas, formuojama minkšta balso ataka, taisyklinga artikuliacija, sinchronizuojami kvèpavimas su fonacija. Gydoma manualine terapija, ivairių metodikų ortofoniniais pratimais. Moksliniais tyrimais įrodyta, kad balso terapija yra veiksminga gydant dirglių gerklų sindromą [9]. Atliktos metaanalizès parodè, kad balso terapija yra veiksminga mažinant gerklų spazmų epizodus, atkaklaus kosulio pasireiškimą ir gerinant gyvenimo kokybę [26].

Gydymas neuromoduliatoriais. Atkaklaus kosulio priepuoliai gydomi neuromoduliatoriais [13]. Skiriamų vaistu dozè didinama palaipsniui iki atsako. Esant atsakui, gydymas pratęsiamas iki 3 mènesių. Vaistai nutraukiami taip pat palaipsniui, mažinant vaisto dozę. Gydant DGS neuromoduliatoriais, prognozuojamas stiprus pagerèjimas, bet ne 
pasveikimas. Nesenai atlikta Cohen ir kolegų sisteminė 8-ių šia tema publikuotų straipsnių analizè atskleidè, kad dažniausiai skiriamas šiuolaikinis neuromoduliatorius yra gama amino sviesto rūgšties analogas - gabapentinas, kurio dozè didinama palaipsniui iki atsako - nuo $100 \mathrm{mg}$ per dieną iki optimalios - 900-1800 mg per dieną, šią dozę suvartojant per du tris kartus (2 lentelè). Vartojant neuromoduliatorius, pacientams gali pasireikšti mieguistumas, galvos svaigimas, gleivinių sausumas, todèl apie šiuos šalutinius poveikius reikia ịspeti pacientus [13].

Priešrefliuksiniai vaistai. Empirinis trumpalaikis (triju ménesių) gydymas protonų siurblio inhibitoriais (PSI) rekomenduojamas tuo atveju, kai DGS sergančiam pacientui vaizdo laringoskopija kartu nustatomi lètinio laringito požymiai arba kartu pasireiškus tipiniams GERL simptomams - rèmeniui, atpylimui [25]. Rizikos pacientams, kurie ilgą laiką (> $1 \mathrm{~m}$.) vartoja PSI, yra vyresnio amžiaus, po menopauzès, serga osteoporoze, atsižvelgiant ị FDA rekomendacijas, rekomenduojama kartu skirti kalcio preparatus [27]. Šiuolaikinès GERL LF gydymo tendencijos taip pat apima slopinančių pepsino aktyvumą preparatų vartojimą $-\mathrm{Mg}$ ir $\mathrm{Na}$ alginatus, šarmini $(\mathrm{pH}>8)$ vandeni, pepsiną neutralizuojančius fitochemikalus, $\mathrm{pH}$ paremtą antirefliuksinę dietą [28].

Lokalus gerklu jautrumo gydymas intragerklinèmis injekcijomis su lidokainu [29]. Šis gydymo būdas indikuotinas, kai, esant raumenų įsitempimui, balso terapija yra neveiksminga. Dworkin su kolegomis pasiūlè tuo atveju 1-2 proc. 1 $\mathrm{ml}$ lidokaino tirpalo injekuoti į gerklas (balso klostes) translaringiniu priejimu per žiedinę skydo membraną (membrana cricothyroideus). Po lidokaino tirpalo suleidimo, pagal originalią metodiką, kartu siūloma skirti 5 minučių balso terapiją. Lidokainas veikia gerklų gleivinès mechanoreceptorius ir nutraukia hiperfunkcinès fonacijos mechanizmą.

\section{Išvados}

1. Dirglių gerklų sindromas yra daugiafaktorinè patologija, kuri susijusi su padidejusiu gerklų jautrumu skirtingiems dirgikliams ir sukelianti epizodiškai pasikartojančius gerklų spazmus, lydimus disfonijos ir kosulio bei gerklų parestezijos.

2. Dirglių gerklų sindromas diagnozuojamas atsižvelgiant ị būdingus simptomus, laringoskopijos ir išorinès kaklo apžiūros duomenis, rodančius padidejusį gerklų ir kaklo raumenų îsitempimą bei nustatomą simptomų ryši su tam tikrais dirgikliais.

3. Sindromo gydymas yra kompleksinis, apimantis paciento mokymą, balso terapiją, gydymą neuromoduliatoriais ir balso higieną.

\section{Literatūra}

1. Morrison M, Rammage L, Emami AJ. The irritable larynx syndrome. J Voice 1999;13: 447-455.

https://doi.org/10.1016/S0892-1997(99)80049-6

2. Morrison M, Rammage L. The irritable larynx syndrome as a central sensitivity syndrome. Can J Speech Lang Pathol Audiol 2010;34:282-289.

3. Forrest LA, Husein T, Husein O. Paradoxical vocal cord motion: classification and treatment. Laryngoscope 2012;122:844-853. https://doi.org/10.1002/lary.23176

4. Andrianopoulos MV, Gallivan GJ, Gallivan KH. PVCM, PVCD, EPL, and irritable larynx syndrome: what are we talking about and how do we treat it? J Voice 2000;14:607-618. https://doi.org/10.1016/S0892-1997(00)80016-8

5. Shembel AC, Sandage MJ, Abbot KV. Episodic laryngeal breathing disorders: literature review and proposal of preliminary theoretical framework. J Voice 2016 [article in press].

6. Hoy RF, Ribeiro M, Anderson J, Tarlo SM. Work-associated irritable larynx syndrome. Occupational Medicine 2010;60:546551.

https://doi.org/10.1093/occmed/kqq117

7. DePietro JD, Stein DJ, Calloway N et al. U.S. practice variations in the treatment of chronic laryngopharyngeal neuropathy. Laryngoscope 2014;124:955-960. https://doi.org/10.1002/lary.24427

8. Altman KW, Noordzij JP, Rosen CA. et al. Neurogenic cough. Laryngoscope 2015;125:1675-1681.

https://doi.org/10.1002/lary.25186

9. Gibson PG, Vertigan AE. Management of chronic refractory cough. BMJ 2015;351.

https://doi.org/10.1136/bmj.h5590

10. Meyer S, Ptok M. Laryngeal neuropathy and "irritable larynx syndrome" [article in German]. Laryngorhinopatologie 2012;617-24.

11. Bucca CB, Bugiani M, Culla B. et al. Chronic cough and irritable larynx. J Allergy Clin Immunol 2011;127:412-419.

https://doi.org/10.1016/j.jaci.2010.10.038

12. Bastian RW, Vaidya AM, Delsupehe KG. Sensory neuropathic cough: a common and treatable cause of chronic cough. Otolaryngol Head Nech Surg 2006;135:17-21.

https://doi.org/10.1016/j.otohns.2006.02.003

13. Cohen S, Misono S. Use of specific neuromodulators in the treatment of chronic, idiopathic cough: a systematic review. Otolaryngol Head Neck Surg 2013; 148:374-382. https://doi.org/10.1177/0194599812471817

14. Chung KF. Approach to chronic cough: the neurophatic for cough hypersensitivity syndrome. J Thorac Dis 2014;6 (suppl 7):S699-707.

15. Morice AH. Chronic cough hypersensitivity syndrome. Review. Cough 2013;9:14. 
https://doi.org/10.1186/1745-9974-9-14

16. Hull JH, Menon A Laryngeal hypersensitivity in chronic cough. Pulm Pharmacol Ther 2015;35:111-116. https://doi.org/10.1016/j.pupt.2015.08.008

17. Morice AH, McGarvey LPA, Dicpinigaitis PV. Cough hypersensitivity syndrome is an important clinical concept: a pro/ con debate. Lung 2012;190:3-9. https://doi.org/10.1007/s00408-011-9351-y

18. Vertigan AE, Bone SL, Gibson PG. Laryngeal sensory dysfunction in laryngeal hypersensitivity syndrome. Respirology 2013;18:948-956.

https://doi.org/10.1111/resp.12103

19. Traister RS, Fajt ML, Landsittel D. et al. A novel scoring to distinguish vocal cord dysfunction from asthma. J Allergy Clin Immunol Pract 2014;2:65-69.

https://doi.org/10.1016/j.jaip.2013.09.002

20. Gartner-Schmidt JL, Rosen CA, Radhakrishnan N, Ferguson BJ. J Voice. Odor provocation test for laryngeal hypersensitivity 2008;22:333-338.

21. Vertigan AE. Sarah LB, Gibson PG. Development and validation of the Newcastle laryngeal hypersensitivity questionnaire. Cough 2014;10:1. https://doi.org/10.1186/1745-9974-10-1

22. Buchsel PC. Polyvinylpyrrolidone-sodium hyaluronate gel (Gelclair): a bioadherent oral gel for the treatment of oral mucositis and other painful oral lesions. Expert Opin Drug Metab Toxicol 2008;4:1449-54.

https://doi.org/10.1517/17425255.4.11.1449

23. Behrbohm H. Halstabletten mit hyaluronsäure können bei pharyngitis helfen. HNO Nachrichten, Sonderdruck 1, 2011, Springer Medizin, München.

24. Behrbohm H. Hydrogel-komplex bei halsbeschwerden. Forumkompakt. Hals Nasen Ohrenheilkunde 2011.

25. Schwartz SR, Seth MC, Seth HD et al. Clinical practice guideline: Hoarseness (Dysphonia). Otolaryngology Head Neck Surg 2009; 141:S1-31.

https://doi.org/10.1016/j.otohns.2009.06.744
26. Chamberlain S, Birring SS, Garrod R. Nonpharmacological interventions for refractory chronic cough patients: systematic review. Lung 2014;192:75-85.

https://doi.org/10.1007/s00408-013-9508-y

27. Ye X, Liu H, Wu C, Qin Y, Zang J, Gao Q, Zhang X, He J. Proton pump inhibitors therapy and risk of hip fracture: a systematic review and meta-analysis. Eur J Gastroenterol Hepatol 2011;23:794-800.

https://doi.org/10.1097/MEG.0b013e328348a56a

28. Koufman JA, Johnston N. Potential benefits of $\mathrm{pH} 8.8$ alkaline drinking water as an adjunct in the treatment of reflux disease. Ann Otol Rhinol Laryngol 2012; 121:431-34.

https://doi.org/10.1177/000348941212100702

29. Dworkin JP, Meleca RJ, Simpson ML, Garfield I. Use of topical lidocaine in the treatment of muscle tension dysphonia. J Voice 2000; $14: 567-574$.

https://doi.org/10.1016/S0892-1997(00)80012-0

\section{IRRITABLE LARYNX SYNDROME: MODERN DIAGNOSTICS AND TREATMENT}

N. Šiupšinskienė, A. Aukštakalnienė, S. Norkienė

Key words: irritable larynx syndrome, paradoxical vocal cord movement, sensory neuropathy, causes, diagnostics, treatment, hydration.

Summary

The article includes comprehensive description of the definition of irritable larynx syndrome, the main causes and underlying pathogenesis in adults. Also the article ascribes irritable larynx syndrome diagnostics with history, symptoms and laryngoscopic findings. Nowadays basic principles of the syndrome including patients' education, speech therapy, psychotherapy and behavioural management of the symptoms as well as treatment with neuromodulators are discussed. The benefit of voice hygiene and hydration are also described.

Correspondence to: norai_s@yahoo.com

Gauta 2017-09-18 